NEWS

\title{
Blair under fire over Trident 'secrecy'
}

Leading weapons experts and security thinktanks have accused the British government of withholding information needed for proper evaluation of a multibillion-pound proposal to renew the country's fleet of nuclear submarines.

Crucial data on whether the life of the fleet can be extended have not been made public in the run-up to next month's expected parliamentary debate, say the critics. Not releasing the information, they add, fuels fears that the decision will be driven by party politics and industry lobbying rather than by security needs.

Britain's four nuclear submarines, each of which carries up to 16 ballistic Trident missiles and 48 nuclear warheads, will reach the end of their design life in the early 2020 s. In a report released last December, the government argued that it would not be prudent to extend the vessels' lives - and that work on replacements should start this year, at a probable cost of between $£ 15$ billion and $£ 20$ billion (US $\$ 30$ billion to $\$ 40$ billion). Some critics say that the decision is being rushed so that Prime Minister Tony Blair can secure the replacement of the submarines before he steps down this summer.

But the decision to renew the fleet rests on broad engineering arguments, such as references to past submarine programmes, rather than on a detailed cost analysis. The Ministry of Defence says that releasing the specifics of its plan would amount to telling the world how its submarines work. Others say that this is an exaggeration and that withholding the information prevents a fair comparison with the main alternative: renovating the fleet to extend its life by 10 to 20 years.

${ }^{\alpha}$ There is absolutely not enough information out there to make a decision", says Richard Garwin, a physicist and senior adviser on nuclear weapons and other security questions to the US government. Garwin was one of several witnesses who gave evidence on proposed replacements for the submarines to the House of Commons Defence Committee on 23 January.

But attempts to gather such information have been rebuffed. A London-based think-tank, the British American Security Information Council (BASIC), says that it has submitted around eight questions under freedom of information legislation to the Ministry of Defence. Answers to all technical questions, such as whether the submarine hull or the reactor would need to be renovated first, were declared classified. The environmental group Greenpeace has had similar requests and subsequent appeals turned down.

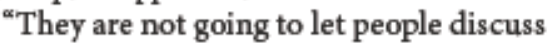
the technical details, even if the information is not particularly sensitive," says Paul Ingram, a senior analyst at BASIC. The ministry says that it answered many of the questions submitted, but that it has to balance public debate with the need to avoid helping nations that might want to undermine Britain's defences. A ministry spokesman said that no state currently had the capability and intent to do so, but that such a threat could potentially arise in coming decades.

Attempts by Britain's top scientific organizations to join the debate have also been rejected.

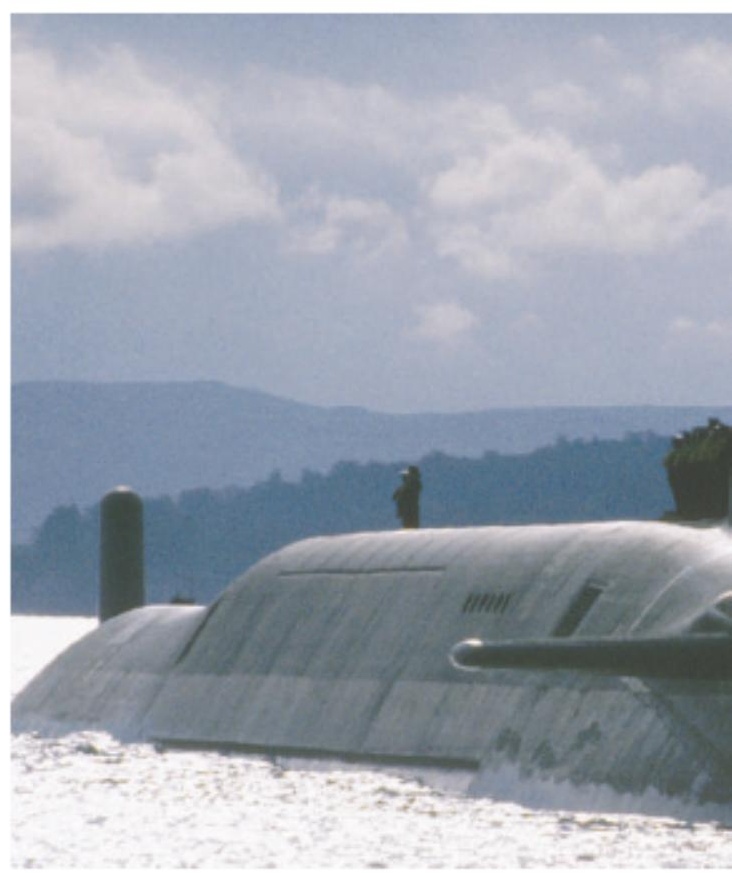

The Royal Society wrote to Roy Anderson, the Ministry of Defence's chief scientific adviser, last April and offered to suggest experts who could assist in the ministry's deliberations. The society was told a month later that the ministry had the matter covered. "We've been running the submarines safely for 40 years," explains Matthew Willey, a ministry spokesman. "There's a huge wealth of expertise here."

But that attitude, says Garwin, contrasts starkly with that in the United States, where outside specialists are often granted the security clearance needed to assess scientific and engineering aspects of military decisions.

\section{California institute woos NIH stem-cell chief}

The California Institute for Regenerative Medicine (CIRM) is courting the top stem-cell official at the US National Institutes of Health (NIH) to take over as its president.

James Battey, who since 2002 has coordinated stem-cell research at the NIH as chair of its Stem Cell Task Force, was approached by a member of the CIRM's governing committee in December after its current president, Zach Hall, announced his resignation (see Nature 444, 803 ; 2006).

Since then, Battey has been excused from all stem-cellrelated work at the NIH, agency spokeswoman Marin Allen has confirmed. He remains in his position as director of the National Institute on Deafness and Other Communication Disorders in Bethesda, Maryland. "NIH is grateful for the leadership he has provided and is honouring his privacy," Allen wrote in an e-mail.

Battey was considered as a candidate last time the CIRM was looking for a president, in early 2005 when the \$3-billion institute was newly minted. It ended up hiring Hall.

The 14-member search committee charged with finding the institute's next president was scheduled to hold its first meeting by teleconference on 31 January. Two days earlier, CIRM spokesman Dale Carlson called any discussion of Battey's candidacy premature. "The search committee hasn't met. They've not retained an [executive search] firm. They haven't posted a job description," he said.

The search committee hasn't discussed a shortlist "with any real seriousness", member Joan 
